\title{
When We Look At The Supervisor Image In The Mirror, What Do We See? The Supervisors' Mirror Image Regarding Doctoral Supervision
}

\author{
Isabel Ribau Coutinho \\ PhD Sustainable Chemistry, PhD Educational Sciences \\ Centro Interdisciplinar de Ciências Sociais, Universidade Nova de Lisboa, Portugal
}

\begin{abstract}
Studies regarding doctoral education can focus the PhD student, the supervisor, higher education institution (policy, curriculum, professional career support, culture, among others). PhD students, supervisors and higher education institution, constitute three keys for the same door (doctoral education), and without one of them, the door can't be well open. Choose which of them should be analyzed is the researcher responsibility, as present data and look carefully to it. During the last years' doctoral education and the doctoral supervision process at UNL as been studied, looking to PhD students, supervisors and institution [1-5]. In the present research, the focus is on supervisor perception. It is important to know supervisor opinion, to attempt and captures their perceptions regarding the doctoral supervision process. When the supervisor thinks and responds to surveys regarding supervision, he/she is presenting an image of himself/herself. This study occurred among the PhD supervisor population at a Science engineering school (Faculdade de Ciências Tecnologia) at Universidade Nova de Lisboa, a Portuguese Higher education institution, with a footprint in the research area. It was possible to capture the image that reflected in the mirror when the supervisor looked. The unexpected image reflected is of a researcher and not a supervisor. When they look to their doctorates, they generally see future technicians/ qualified workers and not a future researcher. Nonetheless, they consider that to finish the PhD, doctorates have to acquire the research profile. This mismatch is consistent with the reality, where attrition exists and many students think to live the academy after the enrollment in the PhD.
\end{abstract}

\section{INTRODUCTION}

Since the nineties of the twenty century, doctoral education is analyzed all over the world $[6,7]$. Not only because the population that is enrolled increase and diversified itself, but also because increased its importance for development and innovation in societies [8-11]. But still a black box [12] and a private place [13]. It is a challenge to study, as difficulties to obtain data exist and, the problems detected in the last forty years persist. Namely the supervision, training and practice (lack of quality and timely feedback, contact time and meeting qualities, availability to discharge supervisory duties) [14] but also the attrition/time to completion and the student's academic dropout $[15,16]$. 
The parties accountable in the doctoral education process comprise the PhD student, the supervisor, and the institution, with the role of the supervisor being emphasized [12-16].

Several guidelines have emerged in recent years, from the European Commission and associations of higher education institutions, like League of European Research Universities (LERU) and the European University Association (EUA), for doctoral education regarding the institutional role, supervisory practices, and role but also PhD students' journey and expectations regarding the enrolment in a doctorate. Also, governments reflected about their policy concern the doctoral education: importance, goals, financial support, impact on society, and so one. A milestone for Europe was, the Lisbon strategy (2000) that emphasize the third cycle as the bridge between research area and higher education area, the Salzburg Principles I (2005) and the Salzburg Principles II (2010), among others. The changes proposed, are reflected in the role and nature of supervision, and demand efficient use of technology, interpersonal relationship management, changes in the doctoral program not only in their modalities, structure, content, and design but also in different types regarding their goals $[13,17]$. These imply adjustments in practice, tasks, and training of doctoral research. It is important to highlight that, "Economically, large amounts of money are spent by institutions to recruit doctoral students, and once doctoral students are admitted institutions often pay for their tuition in exchange for student assistantships (Gardner, 2009). This money is essentially lost if the student does not complete the degree program."[17]. Research data continue to confirm, the difficulties felt by students, to complete their PhD degree $[1,8-9,15-17]$.

Successful doctoral training involves the development of different areas and is a complex multitask journey. As Chakraverty (2020) refers "Successful graduate training involves developing higher-order thinking/reasoning and scientific communication skills that are rather complex (Lovitts, 2005) and require psycho-social support, the integration in the academy and the sense of belonging but also and supervisor support" [18]. Dealing with self and the other's expectation (family, supervisor, academy among others) can be challenging for doctoral student's mental health, as the relation with the supervisor or team supervisors during the research training [1820]. During the PhD, researchers are formed, and they can be developers, innovative and creative - a doctorate should think "out of the box" but also "inside the box". These characteristics must be developed during the doctorate when the researcher is constructed, based on frontier knowledge, research competences as creativity, originality, innovation, and critical thinking, but also in leadership versus teamwork, independence, autonomy [21-24] and all of these with the constraints that appear during the development of the research process [25].

To perspective the future of the Portuguese research area, it's crucial to perceive which ways are chosen by the Portuguese doctoral Supervisors. The question that is urgent to respond is: The academic training given by supervisors shapes the PhD students, as follower/executor or innovator/researcher? As the time to "produce" an executor/qualified technician is shorter than the time to "produce" an innovator, the tendency of the supervisors is generally too opted for the first one [24]. Then the knowledge construction is hindered and, the innovations don't happen.

Fulgence study (2019) establishes five mechanisms through which doctoral supervisors develop supervision skills: the supervision process, doctoral education, institutional guidelines, institutional training courses, and individualized learning [26]. This researcher refer " Theory- 
Coutinho, I. R. (2021). When We Look At The Supervisor Image In The Mirror, What Do We See? The Supervisors' Mirror Image Regarding Doctoral Supervision. Advances in Social Sciences Research Journal, 8(2) 398-410.

based reasons make similar assumptions that supervisors possess doctoral supervision skills emanating from their previous experience as doctoral and masters students (Durette et al., 2016; Lee, 2008; Maguire \& Delahunt, 2017) as well as from mentoring and postdoctoral programs (Sefotho, 2018; Åkerlind, 2005). By and large, most supervisors rely on their experience of being supervised during their doctoral studies (Askew et al., 2016; Bastalish, 2017)" [26]. But is this experience/training sufficient to supervise a PhD student today? As a researcher points out "There is a need to offer supporting evidence that the skills they possess qualify them to supervise doctoral students and the overall doctorateness process in the contemporary world (Trafford \& Leshem, 2011; Yazdani \& Shokooh, 2018)" [26].

To minimize the effects of "bad supervisors", and to support new doctorate forms, many institutions, over the past decades, promote the co-supervision/ team supervision/joint supervision in doctoral study programs [27-30]. Dyadic supervision or team supervision can answer better to the new doctoral research challenge than a single supervisor. But the complexity of the supervision process increase and can hinder the supervision journey. Nonetheless, research evidence indicates that if the supervisor team is efficient, it can help PhD students' conclude their $\mathrm{PhD}$ degree [28-30].

In this research will present the institution policy regarding supervision based in public documents. Them the supervisors view will be presented and discussed. Finally some conclusions will be reported as the limitations.

\section{METHODOLOGY}

The research aims were: capture the supervisor profile using their lens; identify the curriculum developed by them; to perceive the most relevant characteristics that influence the $\mathrm{PhD}$ completion from the $\mathrm{PhD}$ supervisor point of view. A questionnaire, to capture the supervisors' perceptions regarding the supervisor profile, skills to develop during the $\mathrm{PhD}$ (curriculum) and the characteristics relevant to complete the $\mathrm{PhD}$, from the supervisor lens, was constructed. This surveys had open and ended questions. In the ended questions, the respondents had to assign the degree of importance, of items, according to a scale with: Very important, important, slightly important and not important.

This survey was delivered, via institutional e-mail at NOVA School of Science and Technology (FCT-UNL), to PhD supervisors. This school belongs to Universidade Nova de Lisboa, which is a public higher education institution, with high levels of research inputs. The survey was open for three months. Forty PhD supervisor answered the survey.

\section{Institution Public Policy Regarding Supervision}

\section{RESULTS AND DISCUSSION}

To be a PhD supervisor at NOVA School of Science and Technology (FCT-UNL), the only requirement is a doctoral degree [Ribau \& Alves, 2017]. So this implies that have a doctoral degree give the competence to supervise a $\mathrm{PhD}$, being the profiles similar. A-frame was constructed having this in mind, Table 1. 
Table 1. Requirements to be a supervisor (decree-Law no. 74/2006, of 24 March, chapter IV (PhD), article 28 (PhD degree), based in the Dublin descriptors (2004).

\begin{tabular}{|c|c|}
\hline \multicolumn{2}{|c|}{ Characteristics that the supervisor should have (similar to the doctorate) } \\
\hline Professional & Academic \\
\hline $\begin{array}{l}\text { c) Ability to conceive, design, adapt and } \\
\text { carry out a significant investigation } \\
\text { respecting the requirements imposed by } \\
\text { academic quality and integrity standards; }\end{array}$ & $\begin{array}{l}\text { a) Ability to systematically understand a scientific field of } \\
\text { study; }\end{array}$ \\
\hline $\begin{array}{l}\text { f) Be able to communicate with their peers, } \\
\text { the rest of the academic community and } \\
\text { society in general about the area in which } \\
\text { they are specialized; }\end{array}$ & $\begin{array}{l}\text { b) Competencies, skills and research methods associated } \\
\text { with a scientific domain; }\end{array}$ \\
\hline $\begin{array}{l}\text { g) To be able in a knowledge-based society, } \\
\text { to promote, in an academic and or } \\
\text { professional context, technological, social } \\
\text { or cultural progress. }\end{array}$ & $\begin{array}{l}\text { d) Have carried out a significant set of original research } \\
\text { works that have contributed to the expansion of the frontiers } \\
\text { of knowledge, part of which deserves national or } \\
\text { international dissemination in publications with a selection } \\
\text { committees; }\end{array}$ \\
\hline & $\begin{array}{l}\text { e) To be able to critically analyse, evaluate and synthesize } \\
\text { new and complex ideas; }\end{array}$ \\
\hline
\end{tabular}

Though the supervision is typically a professional relationship, usually it became also a personal one. But the personal profile to become a supervisor is missing in the legislation and regulations of FCT-UNL. There is no demand for formation regarding supervision for the legislator. And the assumption that a good researcher or a higher education teacher is a good supervisor is assumed by the legislator (to be a higher education teacher in UNL, there are no special formation demands, only the PhD degree.) But there other gaps in these characteristics, teamwork skills aren't contemplated nor the leadership competence. So, some questions arise. How can researchers work well in a team or network if they aren't trained for it, during the PhD? How can researchers propose new research projects if they don't know how to lead a team?

In recent years a change started in UNL. The supervision started to be looked carefully, and data regarding attrition were presented to the public [Ribau \& Alves, 2018]. A two-days course, voluntary and free, named "Developing supervisory skills course "(https://www.unl.pt/curso/ensino/escola-doutoral/curso-de-desenvolvimento-decompetencias-de-supervisao) is proposed by UNL doctoral school, since 2012. As it says in the description: " Although supervision is one of the most important elements of academic work, the majority of current supervisors do not receive any specific training in this area. This course aims to fill this gap, focusing on the dimensions of student-supervisor interaction as a key element for the success of a $\mathrm{PhD}$ course. Topics covered in this course include Supervisory context; Interpersonal relationship; Leadership, motivation and self-knowledge; the field supervision process; Problem identification; Conflict management." And it also identifies goals "Provide participants with a conceptual framework for supervisory activity in a postgraduate context, particularly about issues related to the interaction between student and supervisor; Emphasize the relevance of dimensions such as leadership, motivation and self-knowledge in the supervision process; Illustrate specific adult learning issues that may be relevant for supervision; Facilitate the identification of the most common problems that may arise during supervision; Improve the 
Coutinho, I. R. (2021). When We Look At The Supervisor Image In The Mirror, What Do We See? The Supervisors' Mirror Image Regarding Doctoral Supervision. Advances in Social Sciences Research Journal, 8(2) 398-410.

ability to manage the most common conflicts, using an appropriate approach." But institution also indicates WHO IS IT INTENDED FOR: "The course is aimed at NOVA doctorates (professors, researchers and postdocs), as well as doctorates from other institutions (teachers, researchers and postdocs) who guide PhD theses for students at the NOVA University of Lisbon."

So this information, not only allows the reader to perceive that the institution is aware of the above gaps but also identifies them and proposes a remediation process. It is interesting to look the characteristics that supervisors must have: leadership, motivation, know the supervision process and the adult learning process, know how to identify and manage conflicts and supervision problems, but also how to manage the interrelation with the students. These themes, emphasize the supervision process as a teaching and learning process, which involve personal, professional and academic issues, and not only a translation of knowledge between the supervisor and the PhD Students.

It is should notice that the Scientific Orientation, of a $\mathrm{PhD}$, is characterized in the article 16 of the document entitled "General regulation of the FCT -UNL study cycles leading to the UNL PhD degree (3rd cycle of higher studies)". In this regulations it is written " 1 - The scientific orientation of a doctoral student will be in charge of a professor or a doctoral researcher; 2 - The joint guidance regime is mandatory whenever the supervisor is external to the FCT -UNL, with the co orientation exercised by PhD professor or researcher at FCT -UNL; 3 - In other situations where the guidance regime is justified jointly, can be appointed as teacher co-supervisors or PhD researchers, or experts of merit recognized by the Scientific Council of FCT -UNL, after hearing the Department Council dominant in its execution; 4 - A PhD student can have a maximum of one supervisor and two co-supervisors; 5 - In addition to the student's scientific guidance, the supervisor is responsible for assessing the student's training needs, and propose their studies plan to the Scientific Committee. It is also supervisor responsibility to give an opinion, on the annual progress reports submitted by the student, and on the submission of the doctoral thesis, taking into account the thesis monitoring committee reports" (Faculdade de Ciências e Tecnologia, Regulamento n. 487/2014, Diário da República, 2. série - N.o 209 - 29 of October 2014).

The institution promotes team supervision and, the supervisors' responsibilities for assessing the student's training needs and, propose their studies plan to the Scientific Committee if necessary.

\section{The Degree of Importance of Some Supervisors' Competences in the Supervisors' Eyes}

When supervisors respond to the survey, they reflect in their own experience (as PhD students and supervisors). This is a strategy of professional development, as they reflect in their practice during and after doing it.

Knowing the importance of some characteristics regarding supervisors' competence, professional development, individual and psychological attributes, can help catch their point-of-view regarding supervision.

In the supervisor profile competence, a detailed classification is present: "Skills in the research area", "PhD research process monitorization" "Guidance", "Feedback", "Motivational skills", "leadership skills", "Personal attributes", Supervisor rule in as integrator , Table 2. 
Table 2. The degree of importance on a supervisor of...

\begin{tabular}{|c|c|c|c|c|c|c|}
\hline \multirow{2}{*}{\multicolumn{3}{|c|}{ The degree of importance on a supervisor of... }} & \multicolumn{4}{|c|}{ Percentage of supervisor } \\
\hline & & & $\begin{array}{c}\text { Very } \\
\text { important }\end{array}$ & Important & $\begin{array}{c}\text { Slight } \\
\text { important }\end{array}$ & \\
\hline \multirow{27}{*}{ 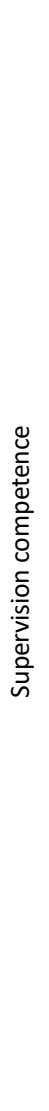 } & \multirow{2}{*}{ 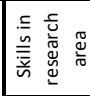 } & Have knowledge of the research topic/area/theme & 88 & 13 & 0 & 0 \\
\hline & & Have knowledge of research methodologies & 83 & 18 & 0 & 0 \\
\hline & \multirow{4}{*}{ 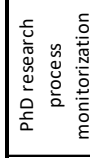 } & Indicate deadlines for the tasks & 43 & 58 & 0 & 0 \\
\hline & & Monitor the course of doctoral research & 38 & 63 & 0 & 0 \\
\hline & & Accompany the doctoral student in doctoral research & 28 & 68 & 5 & 0 \\
\hline & & Evaluate the performance of doctoral students & 28 & 63 & 10 & 0 \\
\hline & \multirow{2}{*}{ 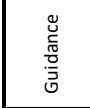 } & $\begin{array}{l}\text { Collaborate with the doctoral student in solving problems that arise } \\
\text { in the research he/she is carrying out }\end{array}$ & 65 & 33 & 3 & 0 \\
\hline & & Propose appropriate readings to the research to be developed & 45 & 40 & 15 & 0 \\
\hline & \multirow{5}{*}{ 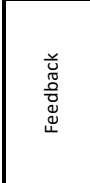 } & Be honest in his/her opinions about the doctoral student work & 80 & 20 & 0 & 0 \\
\hline & & Give quality feedback & 78 & 23 & 0 & 0 \\
\hline & & Give constructive feedback & 65 & 35 & 0 & 0 \\
\hline & & Be clear in the comments to the work of the doctoral student & 63 & 38 & 0 & 0 \\
\hline & & Provide timely work feedback & 53 & 45 & 3 & 0 \\
\hline & \multirow{2}{*}{ 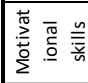 } & Motivate the doctoral student during doctoral research & 50 & 48 & 0 & 3 \\
\hline & & Encourage the doctoral student during the doctoral research & 50 & 45 & 5 & 0 \\
\hline & \multirow{4}{*}{ 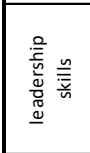 } & Be open to new ideas / proposals for doctoral research & 55 & 43 & 3 & 0 \\
\hline & & Knowing how to manage conflicts & 48 & 48 & 5 & 0 \\
\hline & & Know how to manage supervision time & 38 & 58 & 5 & 0 \\
\hline & & Allow doctoral students to choose their research tasks & 13 & 63 & 25 & 0 \\
\hline & \multirow{6}{*}{ 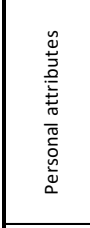 } & Be available to speak with doctoral students & 68 & 33 & 0 & 0 \\
\hline & & Ensure that doctoral candidates complete their doctoral thesis & 58 & 40 & 3 & 0 \\
\hline & & Show interest in the doctoral student's career & 45 & 53 & 3 & 0 \\
\hline & & Be attentive to the needs of students & 43 & 55 & 3 & 0 \\
\hline & & Show that feel responsible for the failure/success of the doctorate & 40 & 43 & 15 & 3 \\
\hline & & Be a learning facilitator & 30 & 65 & 5 & 0 \\
\hline & \multirow{2}{*}{ 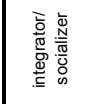 } & Integrate the student in the research group & 50 & 50 & 0 & 0 \\
\hline & & Be the link between the student and the academy & 20 & 48 & 30 & 3 \\
\hline \multirow{8}{*}{\multicolumn{2}{|c|}{ 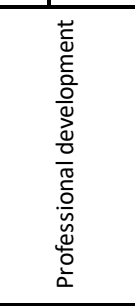 }} & Publish papers & 48 & 53 & 0 & 0 \\
\hline & & Have a great deal of knowledge regarding supervision & 45 & 50 & 5 & 0 \\
\hline & & Know how to teach & 40 & 50 & 10 & 0 \\
\hline & & Having a network with other research groups & 33 & 63 & 5 & 0 \\
\hline & & Go to congresses and conferences & 33 & 58 & 8 & 3 \\
\hline & & Assess his/her supervisor process (do the self-assessment) & 25 & 63 & 10 & 3 \\
\hline & & Participate in international projects & 25 & 60 & 13 & 3 \\
\hline & & Having experience in supervision & 23 & 58 & 20 & 0 \\
\hline \multirow{10}{*}{\multicolumn{2}{|c|}{ 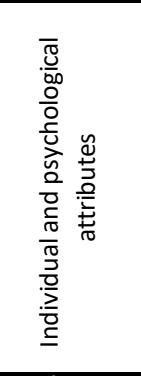 }} & Be critical and self-critical & 75 & 25 & 0 & 0 \\
\hline & & Be loyal to the doctoral student & 70 & 28 & 3 & 0 \\
\hline & & Promote ethical attitudes. & 65 & 30 & 5 & 0 \\
\hline & & Be demanding & 60 & 38 & 3 & 0 \\
\hline & & Be friend / empathize & 53 & 48 & 0 & 0 \\
\hline & & Be calm / pacific & 50 & 48 & 3 & 0 \\
\hline & & Be accessible & 50 & 50 & 0 & 0 \\
\hline & & Be creative & 50 & 50 & 0 & 0 \\
\hline & & Be present & 48 & 48 & 5 & 0 \\
\hline & & Be flexible & 20 & 78 & 3 & 0 \\
\hline
\end{tabular}

The most valued characteristics on a supervisor, to do supervision, in the supervisors' lens, are their skills in the research field and the supervisor feedback. They consider a good supervisor as a good researcher. Fewer see a supervisor as a guide and a researcher constructor. In this sense, motivate or encourage the doctoral student, during the doctoral research, are not very important 
for half of the respondent supervisors. "Be the link between the academy and the PhD student" (assign as very important by only $20 \%$ of the supervisors), "integrate the students in the research group" (assign by half of the supervisors as very important) or "to monitor/accompanied the PhD research process" are not very important to supervisors. This point of view is corroborated by the percentage of supervisors that consider very important "Have a great deal of knowledge regarding supervision" - only 45\%. Here, it is important to remember that accompany and support doctorates are supervisors attributes/ responsibilities in institutions lens (Faculdade de Ciências e Tecnologia, Regulamento n.․ 487/2014, Diário da República, 2. ․ㅗ série - N. $209-29$ of October 2014) but also have formation regarding supervision.

It's also possible to see, from data, that the items regarding professional development were chosen as very important for less than half of the respondents, Table 2.

Concerning to individual and psychological attributes the characteristic that is the most assign as very important is "Be critical and self-critical" (assign by 75\% of the respondents), followed by "Be loyal to the doctoral student $(70 \%$ of the respondent assign this issue)and "promote ethical skills" (assign by $60 \%$ of the supervisors), Table 2.

Surprisingly, the leadership skills are not considered very important for supervisors, which is nonsense as they are the leader of the supervision process. The supervisor is responsible for the $\mathrm{PhD}$ research process, as he assumes the supervision process and the type of leadership change during the $\mathrm{PhD}$ research process. Firstly the supervisor leads/guide the $\mathrm{PhD}$ project, but at the end should be the doctorate. This change in leadership style is very important for doctorate independence and autonomy development.

\section{Main Skills to Be Developed By the Doctoral Student during the Phd from the Supervisor Point of View}

The skills developed by doctorates, guided by supervisors, are related to the supervisors understanding of the finalities of having a $\mathrm{PhD}$. If the supervisor considers the doctorate as a future technician / skilled worker, he/she will focus on their technical and research methods development. If they see the PhD student as a future independent researcher, they will focus on research skills, leadership skills and teamwork, and doctorate integration in the academic/ research field. If they consider the $\mathrm{PhD}$ student a future science communicator/ disseminator, they will promote communication skills, technical and research skills. The first view is the most narrowing of the three and deprives the doctoral path of meaning. 
Table 3. Main skills to be developed by the doctoral student during a doctorate from the supervisor point of view. (RS-researcher skills; SCS- Science Communication Skills; TWS-teamwork Skills; RLResearch Leadership)

\begin{tabular}{|c|c|c|}
\hline \multicolumn{2}{|r|}{ Main skills to be developed by the doctoral student during the PhD } & $\begin{array}{c}\text { Percentage of } \\
\text { supervisors who }\end{array}$ \\
\hline \multirow{19}{*}{ 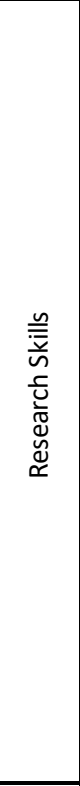 } & Time management & $85 \%$ \\
\hline & Research / investigation capabilities / skills & $70 \%$ \\
\hline & Ability to work autonomously & $70 \%$ \\
\hline & Ability to generate new ideas/knowledge & $68 \%$ \\
\hline & Ability to adapt to new situations & $65 \%$ \\
\hline & Critical and self-critical skills & $63 \%$ \\
\hline & Research autonomy & $63 \%$ \\
\hline & Conceptual knowledge in a specific research area (Know-how) & $55 \%$ \\
\hline & Ability to innovate ("out-of-the-box") & $50 \%$ \\
\hline & Creativity & $50 \%$ \\
\hline & Ethical skills & $50 \%$ \\
\hline & $\begin{array}{l}\text { Ability to deal with complex problems (formulating problems and proposing ways to } \\
\text { solve them) }\end{array}$ & $48 \%$ \\
\hline & Ability to learn & $43 \%$ \\
\hline & Ability to put one's ideas into question (self-criticism) & $43 \%$ \\
\hline & Ability to apply knowledge in new situations & $40 \%$ \\
\hline & Basic general knowledge in the field of study & $30 \%$ \\
\hline & Capabilities/skills of using technical software (use of specific programs) & $28 \%$ \\
\hline & Procedural knowledge in a specific research area (Know-how) & $28 \%$ \\
\hline & Skills in the area of problem-solving & $25 \%$ \\
\hline \multirow{6}{*}{ 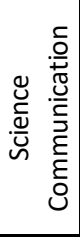 } & Ability to analyze and synthesize & $90 \%$ \\
\hline & Oral and written communication in a non-native language & $73 \%$ \\
\hline & Oral and written communication in the native language & $33 \%$ \\
\hline & Ability to communicate with non-specialists & $30 \%$ \\
\hline & Valuing diversity and multiculturalism & $3 \%$ \\
\hline & Capabilities/skills of using simple software (Word, Excel, etc.) & $23 \%$ \\
\hline \multirow{4}{*}{ 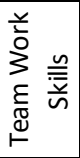 } & Ability to work in an interdisciplinary team & $58 \%$ \\
\hline & Teamwork & $58 \%$ \\
\hline & Ability to work in an international context & $45 \%$ \\
\hline & Ability to collaborate with peers and researchers & $40 \%$ \\
\hline \multirow{7}{*}{ 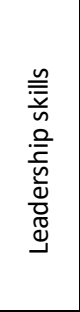 } & Ability to design a project & $38 \%$ \\
\hline & Project planning & $38 \%$ \\
\hline & Ability to apply knowledge in practice & $35 \%$ \\
\hline & Initiative and entrepreneurial thinking & $30 \%$ \\
\hline & $\begin{array}{l}\text { Develop a broad view (holistic) of the issues to anticipate problems and } \\
\text { propose solutions }\end{array}$ & $28 \%$ \\
\hline & Competencies related to decision-making & $23 \%$ \\
\hline & Leadership ability & $3 \%$ \\
\hline
\end{tabular}

Data shows (Table 3) that in these supervisor's lens, the skills to be developed by the $\mathrm{PhD}$ students are the ability to analyse and synthesise (communication skill) and time management (research skill), followed by "Oral and written communication in a non-native language". Assign by $70 \%$ of the supervisors is "Research/investigation capabilities/skills" and "Ability to work autonomously". Few supervisors value leadership skills (only 38\% consider that PhD students should develop them). The items with this percentage (38\%) are linked to the research development: "Ability to design a project" and "Project planning". Only 30\% of the respondents' supervisors assign as the main skill to be developed by doctorates the "Initiative and entrepreneurial thinking". "Develop a broad view (holistic) of the issues to anticipate problems 
Coutinho, I. R. (2021). When We Look At The Supervisor Image In The Mirror, What Do We See? The Supervisors' Mirror Image Regarding Doctoral Supervision. Advances in Social Sciences Research Journal, 8(2) 398-410.

and propose solutions" were assigned by only $28 \%$ of the supervisors, which indicate that the learning process focuses on the $\mathrm{PhD}$ project (it is not a rich process of learning and is restrict). Regarding teamwork ("Ability to work in an interdisciplinary team", and "Teamwork") only 58\% of the supervisor assign as the main skill to be developed by the PhD student. The leadership skills, essentially to lead a project, be independent and do autonomous research, are considered the main competence, to developed by doctorate, only by $38 \%$ of supervisors.

It is possible from the data to conclude that almost forty-two per cent of the respondent supervisors see their PhD students as future technicians / skilled workers but not researchers. They will not develop teamwork skills, which are very important nowadays, as almost all research groups use networks and work as a team. And the $\mathrm{PhD}$ research process generally is poor and restricted to it. Considering data, and the formation/education/ instruction that emerges from it, it is possible to conclude that, a large number of supervisors is forming $\mathrm{PhD}$ students to become qualified workers.

\section{The Importance of Some Characteristics in the Phd Completion from the Supervisor Point of View}

To catch from the supervisor's eyes the most relevant characteristics that the PhD students must have to complete the PhD, the supervisor had to choose them from a list, Table 4.

The most assign characteristics are personal and not professional or academic. Eighty-eight of the supervisors choose "Be motivated" as the most relevant, characteristic of the doctorate to complete de PhD. Followed by "Be available to carry out doctoral research" (ascribe by 83\%), and "Carefully carry out research tasks, with accuracy and precision" ( assigned by 73\%). "know how to manage time" was indicated by $70 \%$ of the respondents as being important for the $\mathrm{PhD}$ completion, "Be resilient" for $68 \%$ and "Be picky/demanding with himself" by $67 \%$. "Be honest regarding his/her research" was assigned by $64 \%$ and $63 \%$ indicated that "Be present" was one of the characteristics that doctorates should have to complete the PhD.

Only after these characteristics appear an academic characteristic related to research skills, assigned by $60 \%$ of the supervisors' respondents - "Knowing how to write articles/reports/monographs" - followed by other related to the same aspect "Be interventional/participatory in his/her doctoral journey" assign by $58 \%$ of the supervisor. "Have a good academic curriculum" is only relevant for $8 \%$ of the supervisor concerning the $\mathrm{PhD}$ conclusion.

These results are relevant, as they focus on the personal process of the PhD research process. The doctorate personal grows (increasing resilience, motivation, careful in the research, and so one) and the researcher construction during the $\mathrm{PhD}$ Journey emerge as the key to the $\mathrm{PhD}$ conclusion. 
Table 4. The degree of importance of each of these characteristics in a doctorate, to complete the PhD.

\begin{tabular}{|c|c|c|c|c|}
\hline \multirow{2}{*}{$\begin{array}{l}\text { The degree of importance of each of these characteristics in a PhD student, to } \\
\text { complete the PhD }\end{array}$} & \multicolumn{4}{|c|}{ Percentage of supervisor that assign } \\
\hline & $\begin{array}{c}\text { Very } \\
\text { important }\end{array}$ & Important & $\begin{array}{c}\text { Slight } \\
\text { important }\end{array}$ & $\begin{array}{c}\text { Not } \\
\text { important }\end{array}$ \\
\hline Be motivated & 88 & 13 & 0 & 0 \\
\hline Be available to carry out doctoral research & 83 & 18 & 0 & 0 \\
\hline Carefully carry out the research tasks, with accurracy and precision & 73 & 28 & 0 & 0 \\
\hline Knowing how to manage time & 70 & 30 & 0 & 0 \\
\hline Be resilient & 68 & 31 & 0 & 0 \\
\hline Be picky/demanding with himself & 67 & 33 & 0 & 0 \\
\hline Be honest in the opinions about their research work & 64 & 33 & 3 & 0 \\
\hline Be present & 63 & 30 & 8 & 0 \\
\hline Knowing how to write articles / reports / monographs & 60 & 38 & 3 & 0 \\
\hline Be interventional/participatory in his/her doctoral journey & 58 & 40 & 3 & 0 \\
\hline To be organized & 58 & 43 & 0 & 0 \\
\hline Be competent in the doctoral research process & 55 & 45 & 0 & 0 \\
\hline Be available to speak to the advisor & 55 & 45 & 0 & 0 \\
\hline Be critical (self-critical) & 54 & 44 & 3 & 0 \\
\hline Meet deadlines for tasks & 53 & 48 & 0 & 0 \\
\hline Show that feel responsible for the failure or success of their PhD & 50 & 43 & 5 & 3 \\
\hline Collaborate with the supervisor in solving problems that arise in the research & 48 & 53 & 0 & 0 \\
\hline Knowing how to communicate in the mother tongue & 48 & 40 & 10 & 3 \\
\hline Provide timely work feedback & 46 & 51 & 3 & 0 \\
\hline Have a constructive attitude & 46 & 54 & 0 & 0 \\
\hline Be open to new ideas / proposals for doctoral research & 45 & 55 & 0 & 0 \\
\hline Be a good listener & 44 & 51 & 5 & 0 \\
\hline Knowing how to plan research & 44 & 54 & 3 & 0 \\
\hline Know how to communicate (have communication skills) & 43 & 55 & 3 & 0 \\
\hline Know how to monitor is own doctoral research & 41 & 56 & 3 & 0 \\
\hline Know how to communicate (oral and written) in English & 41 & 59 & 0 & 0 \\
\hline Have knowledge of the research topic & 40 & 55 & 5 & 0 \\
\hline Have knowledge of research methodologies & 40 & 50 & 10 & 0 \\
\hline Be creative & 37 & 61 & 3 & 0 \\
\hline Be patient & 33 & 64 & 3 & 0 \\
\hline Propose appropriate research tasks & 33 & 50 & 18 & 0 \\
\hline Know how to self-evaluate his/her performance in doctoral research & 28 & 68 & 5 & 0 \\
\hline Be flexible & 25 & 73 & 3 & 0 \\
\hline Have a good academic curriculum & 8 & 56 & 36 & 0 \\
\hline
\end{tabular}

It is possible to see that there's a lack of connections between results. In the first place, "Motivation" isn't regarded as a priority in the supervisor rule. So the student must have intrinsic motivation after all. A recent paper, Ribau (2020) reported that motivation changes with time, as the disappointment and dissatisfaction of the PhD students with supervision increase [31]. So, it should be supervisors concern, "feed" the students' motivation.

The results regarding the "Main skills that should be developed during the PhD" (Table 3) and these (Table 4), don't match well, too. In the previous data (Table 3), the supervisor is preparing the PhD student to be a qualified worker; now they say that to finish the PhD, the doctorate had to develop characteristics beyond the technician vision- They must have a researcher profile. The question that arises is "Where and with whom the PhD student develop the researcher skills? Probability, in most cases, not with the supervisors' guidance. Maybe in a rich and stimulating 
Coutinho, I. R. (2021). When We Look At The Supervisor Image In The Mirror, What Do We See? The Supervisors' Mirror Image Regarding Doctoral Supervision. Advances in Social Sciences Research Journal, 8(2) 398-410.

research environment, by observing other researchers, reading and writing (and rewriting) their thoughts, data and knowledge, alone or with other peers, they become a researcher. This poorfitting regarding $\mathrm{PhD}$ goals, between supervisors' view and the institution/student view, reflect the supervisor feeling regarding their paper in the supervision process. In most of the cases, they are obligated to do supervision, but they feel truly researchers. As supervisors, they support PhD students with technics, science processes and science field knowledge.

\section{CONCLUSIONS}

"What image (consciously or unconsciously) has the supervisor from themself? " One of the main conclusion in this study is that supervisors, seen themselves, principally as researchers, not as supervisors, researchers developers or research constructors. It is clear that a significant part of supervisors do supervision because they have to (it is an institution imposition).

Many of them aren't the bridge between PhD students and the academy or the research group. The mains skills to be developed by those PhD students are "Ability to analyse and synthesized" and "Time management".

It is surprising that, although many supervisors "educate" $\mathrm{PhD}$ students to be qualified workers, they consider that without researcher characteristics (developed during the $\mathrm{PhD}$ research process) it is difficult to them, to complete the PhD. In this context, the research autonomy, reported by supervisors $(63 \%$ consider that is one of the main skill to be developed during the $\mathrm{PhD}$ ) is an artificial one. Based on data, the autonomy signifies that doctorates can work in the researcher environment, without anyone controlling or teaching, but, they don't have enough independence, entrepreneurial thinking or leadership to design and propose new/innovate projects.

What new knowledge about doctoral education emerged from the present research? and What was expected as research impact?

Firstly, the institution policy, concerning the supervisors' training needs and responsibilities was reported and discussed - since 2012, the higher education institution (UNL) has proposed a short course for supervisors. Secondly, the lack of support given by supervisors is compensated and diminished by the institution. Through the Doctoral School, the institution supports PhD students with short-courses to develop transversal skills and develop a holistic view of the research field. Regarding the research impact, it should be highlighted that, as the supervisors answer the questionnaire, they reflect on their practices and values, becoming aware of them, implies professional development.

The gap between real PhD outcomes felt by PhD students (are qualified workers) and expectations (become a researcher), can explain the attrition and the academy abandoned. Students have dreams, expectations as researchers, that aren't fulfilled. They don't want to be qualified workers but become independent researchers. The vision of doctorate as qualified workers it's deeply rooted in the distorted but latent perception that some supervisors have of acquiring a doctoral degree, and can hinder the $\mathrm{PhD}$ process [31]. 


\section{LIMITATIONS}

The first limitation of this research is the reduced number of supervisors that answer the survey. This behaviour can be related to the lack of importance given by them to the supervision process. This limitation only allows attributing the conclusions to this supervisor population- the respondents' supervisors. Nonetheless, the institution recognises the need for supervisor training which support and corroborate the conclusions.

\section{References}

1. Ribau, I. (2019). Listening and feeling doctoral students' perceptions of their doctoral supervision. The PhD students' point of view. Advances in Social Sciences Research Journal, 6 (12), 206-223. DoI:10.14738/assrj.612.7573.

2. Ribau, I. (2020). Doctoral Supervisors and PhD Students' Perceptions about the Supervision Process in a Young European University. Universal Journal of Educational Research. Vol 8 (1), 36-46. DOI: 10.13189/ujer.2020.080105

3. Ribau, I. (2020). The drop effect at doctoral supervision sea surface. Observing the waves with supervisors' lens. Universal Journal of Educational Research. Vol 8 (5), xxx-xxx

4. Ribau, I. \& Alves, M (2017). Doctoral supervision at NOVA LISBON UNIVERSITY: an exploratory study. The European Proceedings of Social \& Behavioural Sciences. http://dx.doi.org/10.15405/epsbs.2017.10.51

5. Ribau, I. \& Alves, M. (2018). Doctoral supervision at NOVA Lisbon University: an overview. Universal Journal of Educational Research, 6, 2530 - 2542 DOI: 10.13189/ujer.2018.061118.

6. Jones, M. (2013). Issues in doctoral studies-Forty years of journal discussion: Where have we been and where are we going? In Proceedings of the Informing Science and Information Technology Education Conference (pp. 83-104). Informing Science Institute. https://doi.org/10.28945/1859

7. Bastalich, W. (2017). Content and context in knowledge production: a critical review of doctoral supervision literature, Studies in Higher Education, 42, 1145-1157.

8. Baptista, A. (2015). Mature students' voices on the ideal and reality of doctoral supervisors' role and practice. Procedia - Social and Behavioral Sciences, 191, 1544-1551.

9. Baptista, A. \& Huet, I. (2012). Making sense of metaphors about doctoral students' competences: analysis of supervisors' voices. Procedia - Social and Behavioral Sciences, 47, 930-937.

10. Figueiredo, C., Huet, I. \& Pinheiro, M. (2012). Construction of scientific knowledge and meaning: perceptions of Portuguese doctoral students. Procedia - Social and Behavioral Sciences, 69, 755-762

11. Breitenbach, E. (2019). Evaluating a model to increase doctorate program completion rates: A Focus on Social Connectedness and Structure. International Journal of Doctoral Studies, 14, 217-236. https://doi.org/10.28945/4239

12. Shibayama, S, \& Kobayashi, Y. (2017). Impact of Ph.D. training: a comprehensive analysis based on a Japanese national doctoral survey. Scientometrics (2017) 113:387-415. DOI 10.1007/s11192-017-2479-7

13. Park, C. (2005). New variant PhD: The changing nature of the doctorate in the UK. Journal of Higher Education Policy and Management, 27 (2), 189-207.

14. Davis, D. (2019). Students' perceptions of supervisory qualities: What do students want? What do they believe they receive? International Journal of Doctoral Studies, 14, 431-464. https://doi.org/10.28945/4361

15. Castello, M., Pardo, M., Sala-Bubare, A., \& Sune-Soler, N. (2017). Why do students consider dropping out of doctoral degrees? Institutional and personal factors. Higher Education, 74(6), 1053-1068. https://doi.org/10.1007/s10734-016-0106-9 
Coutinho, I. R. (2021). When We Look At The Supervisor Image In The Mirror, What Do We See? The Supervisors' Mirror Image Regarding Doctoral Supervision. Advances in Social Sciences Research Journal, 8(2) 398-410.

16. Sverdlik, A., Hall, N. C., McAlpine, L., \& Hubbard, K. (2018). The PhD experience: A review of the factors influencing doctoral students' completion, achievement, and well-being. International Journal of Doctoral Stud-ies, 13, 361-388. https://doi.org/10.28945/4113

17. Fillery-Travis, A., Maguire, K., Pizzolatti, N., Robinson, L., Lowley, A., Stel, N., \& Lee, A. (2017). Insights from practice: A handbook for supervisors of modern doctorate candidates. Super Prof Doc.

18. Chakraverty, D. (2020). PhD student experiences with the impostor phenomenon in STEM. International Journal of Doctoral Studies, 15, 159-179. https://doi.org/10.28945/4513,

19. Evans, T. M., Bira, L., Gastelum, J. B., Weiss, L. T., \& Vanderford, N. L. (2018). Evidence for a mental health crisis in graduate education. Nature Biotechnology, 36(3), 282. https://doi.org/10.1038/nbt.4089

20. Burt, B. A., Knight, A., \& Roberson, J. (2017). Racializing experiences of foreign-born and ethnically diverse Black male engineering graduate students: Implications for student affairs practice, policy, and research. Journal of International Students, 7(4), 925-943. https://doi.org/10.32674/jis.v7i4.182

21. Durette, B., Fournier, M., \& Lafon, M. (2016). The core competencies of PhDs. Studies in Higher Education, 41(8), 1355-1370. https://doi.org/10.1080/03075079.2014.968540

22. Maguire, M., \& Delahunt, B. (2017). Doing a thematic analysis: A practical, step-by-step guide for learning and teaching scholars. All Ireland Journal of Teaching and Learning in Higher Education, 9(3), 3351-3365.

23. Helfer, F., \& Drew, S. (2019). Students' perceptions of doctoral supervision: A study in an engineering program in Australia. International Journal of Doctoral Studies, 14, 499-524. https://doi.org/10.28945/4368

24. Ana Baptistaa, Liezel Frickb, Karri Holleyc, Marvi Remmikd, Jakob Tesche,Gerlese Âkerlindf, The doctorate as an original contribution to knowledge: Considering relationships between originality, creativity, and innovation. Frontline Learning Research Vol.3 No. 3 Special Issue (2015) 55 - 67 ISSN 2295-3159

25. Medeiros, K., Watts, L. \& Mumford, M. (2017). Thinking inside the box: Educating leaders to manage constraints. Handbook of Research on Creative Problem-Solving Skill Development in Higher Education. (Chp.2, 25-50). Published in the United States of America by IGI Global.

26. Fulgence, K. (2019). A theoretical perspective on how doctoral supervisors develop supervision skills. International Journal of Doctoral Studies, 14, 721-739. https://doi.org/10.28945/4446

27. Taylor, S., Kiley, M., \& Humphrey, R. (2018). A handbook for doctoral supervisors. Routledge.

28. Johansen, B. T., Olsen, R. M., Øverby, N. C., Garred, R, \& Enoksen, E. (2019). Team supervision of doctoral students: A qualitative inquiry. International Journal of Doctoral Studies, 14, 69-84.

29. Pyhältö, K., Vekkaila, K., \& Keskinen, J. (2015). Fit matters in the supervisory relationship: Doctoral students and supervisors' perceptions about the supervisory activities. Innovations in Education and Teaching Internation-al, 52, 4-16. https://doi.org/10.1080/14703297.2014.981836

30. Robertson, M. J. (2017). Team modes and power: Supervision of doctoral students. Higher Education Research \& Development, 36, 358-371. https://doi.org/10.1080/07294360.2016.1208157.

31. Ribau, I (2020). A (de)formed perceptionof the pathway to be taken during the PhD. The influence of time in the student's eyes perception in becoming a researcher.Advances in Social Sciences research journal, 7, 272 308. Doi: 10.14738 /assrj.711.9361. 